\title{
Hoyran Havzasının Yeraltısuyu Akım Modellemesi ile Su Bütçesinin Belirlenmesi
}

\author{
İbrahim İskender Soyaslan ${ }^{1 *}$ \\ ${ }^{1}$ Burdur Mehmet Akif Ersoy Üniversitesi, Mühendislik Mimarlık Fakültesi, İnşaat Mühendisliği Bölümü, Burdur, Türkiye (ORCID: 0000-0001-5282-8094)
}

(İlk Geliş Tarihi 27 Kasım 2019 ve Kabul Tarihi 31 Aralık 2019)

(DOI: 10.31590/ejosat.656606)

ATIF/REFERENCE: Soyaslan, İ., İ., (2019). Hoyran Havzasının Yeraltısuyu Akım Modellemesi ile Su Bütçesinin Belirlenmesi. Avrupa Bilim ve Teknoloji Dergisi, (17), 1184-1197.

$\ddot{\mathbf{O z}}$

Türkiye'nin ikinci büyük tatlı su rezervuarı olan Eğirdir Gölü’nden; sulama, içmesuyu temini, turizm ve su ürünleri üretimi gibi pekçok farklı amaçla yararlanılmaktadır. Eğirdir Gölü’nün, su kalitesinin korunarak optimum su kullanım modelinin belirlenmesi büyük önem taşımaktadır. Bu amaçla; göl su toplama havzasının hidrojeolojik özelliklerinin ve göl ile komşu havzalar arasındaki hidrojeolojik ilişsinin belirlenmesi gerekmektedir. Yağışlara bağlı olarak değişmekle bilikte Eğirdir Gölü’nün yüzey alanı 470 km² ve depolama hacmi 4 milyar $\mathrm{m}^{3}$ 'tür. Yeraltısuyu akım modellemesi yapılan Hoyran (Kumdanlı) Havzası, Göller Bölgesinde bulunan Eğirdir Gölü su toplama havzası içerisinde yer almaktadır. Hoyran havzasında evsel kirletici kaynaklardan kolayca kirlenen yüzey ve yeraltısuları göle boşalmaktadır. Kirlenmiş suların göle etkisini tartışabilmek için, Eğirdir Gölü’nü besleyen havzalardan göle akış karakteristiklerinin belirlenmesi amacıyla yeraltısuyu akım modellemesinin yapılması önemlidir. Hoyran Havzası'nda bulunan kirlilik unsurları tarım, hayvancılık ve kanalizasyon deşarjları sonucunda oluşmaktadır. Çalışma alanı Isparta Açısı olarak adlandırılan tektonik olarak aktif bir bölgede bulunduğundan dolayı, jeolojik yapı modelleme açısından oldukça karmaşıktır. Stratigrafik dizilimde yeralan dört farklı hidrojeolojik birim de model alanında yüzeylenmekte ve basınçlı-serbest yüzeyli akifer özellikleri göstermektedir. Böyle karmaşık bir hidrojeolojik ortamda modelleme yapmak az rastlanılan, ilginç ve zor bir konudur. Bölgedeki akifer tabakalarının geometrik yapısı, modelleme programı MODFLOW'un yatay tabaka kavramına izin vermemiştir. Bu problemin çözmünde, benzetim boyunca farklı tabakalar arasındaki yatay akış için, aynı seviyede bulunan farklı hidrojolojik tabakalar farklı hidrojeolojik özellikleri kullanılarak tek bir tabaka olarak modellenmiştir. Yapılan modelleme sonucunda Eğirdir Gölü’ne yeraltısuyu boşalım miktarı yıllık ortalama 32,47 x $10^{6} \mathrm{~m}^{3}$ olarak belirlenmiştir. Bu model, bölgedeki su kaynaklarının yönetimi ve planlaması için bir araç olarak kullanılabilecektir.

Anahtar Kelimeler: Hoyran Havzası, Yeraltısuyu akım modeli, Modflow, Su bütçesi, Eğirdir Gölü

\section{Determination of Water Budget by Groundwater Flow Modeling of Hoyran Basin}

\begin{abstract}
Turkey's second largest freshwater reservoir Lake Eğirdir; is utilized for many kind of purposes such as irrigation, drinking water supply, tourism and aquaculture production. Determining the optimum water usage model by maintaining the water quality of Lake Eğirdir is of great importance. For this purpose; the hydrogeological characteristics of water collection basin of the lake and the hydrogeological relationship between the lake and neighboring basins need to be determined. Depending on the rainfall changes, the surface area of Lake Egirdir is $470 \mathrm{~km}^{2}$ and the storage volume is 4 billion $\mathrm{m}^{3}$. Hoyran (Kumdanli) Basin, for which groundwater flow modeling made, is located within the Eğirdir Lake water collection basin in the Lakes Region. In the Hoyran basin; surface and groundwater that are easily contaminated from domestic pollutant sources, discharge into the lake. In order to discuss the effects of polluted waters to the lake; it is important to make groundwater flow modeling to determine the flow characteristics from the
\end{abstract}

* Sorumlu Yazar: Burdur Mehmet Akif Ersoy Üniversitesi, Mühendislik Mimarlık Fakültesi, İnşaat Mühendisliği Bölümü, Burdur, Türkiye, ORCID: 0000-0001-5282-8094, isoyaslan@ mehmetakif.edu.tr 
watersheds feeding the Lake Egirdir. Pollution elements in Hoyran Basin are formed as a result of agriculture, livestock and sewage discharges. As the study area is located in a tectonically active region called Isparta Angle, the geological structure is quite complex in terms of modeling. Four different hydrogeological units in the stratigraphic sequence are outcropped in the model area and show pressure-free surface aquifer characteristics. Modeling in such a complex hydrogeological environment is a rare, interesting and difficult issue. The geometric structure of the aquifer layers in the region did not allow the model program MODFLOW's horizontal layer concept. In the solution of this problem, for the horizontal flow between the different layers during the simulation, different hydrogeological layers at the same level are modeled as a single layer using different hydrogeological properties. As a result of the modeling, the groundwater discharge to Lake Eğirdir was determined as $32.47 \times 10^{6} \mathrm{~m}^{3}$ per year. This model can be used as a tool for the management and planning of water resources in the region.

Keywords: Hoyran Basin, Groundwater flow model, Modflow, Water budget, Lake Egirdir.

\section{Giriş}

Göl, baraj ve akarsular olarak tanımlanan yüzey suları ile yeraltısuyunun etkileşimi, yeraltısuyu akım modellemesi ve bütçe hesaplamalarının yapılması için duyarlılık analizleri ve matematiksel modelleme çalışmları son yıllarda giderek artmaktadır. Özellikle bilgisayar yazılım ve teknolojilerindeki gelişmelerle birlikte hidrolik ve hidrojeolojik çalışmaların büyük bölümünde MODFLOW programı ve modülleri kullanılmaktadır (Boyraz, 2011; Lulu ve ark., 2005; Guzman ve ark.,2015). MODFLOW yazılımı atıksuların çevresel etkileri (Hussien ve ark.,2017), yeraltısuyu akışındaki zamansal değişimlerin belirlenmesi (Berehanu ve ark., 2017), kararlı şartlarda yeraltısuyu simülasyonu (Gebrekirstos, 2009), yeraltısuyu ile akarsu arasındaki etkileşim (Abbas ve ark., 2018; Yitbarek, 2009; Birhanu, 2012), maden atık sularının akış simülasyonu (Guorui ve ark., 2019) ve yeraltısularında kirlilik taşınımı (Tesfaye, 2009) gibi spesifik konularda kullanılmaktadır. Bu çalışmada PMWIN ve MODFLOW yazılımları birlikte Eğirdir Gölü kuzeydoğusunda yer alan Hoyran Havzası'nın yeraltısuyu akım modellemesi için kullanılmıştır.

Türkiye'nin dördüncü büyük doğal tatlı su gölü olan Eğirdir Gölü’nden; bölgede sulama, içme suyu sağlanması, su ürünleri üretimi ve turizm vb. farklı amaçlar için yararlanılmaktadır. Bölge için büyük önem taşıyan Eğirdir Gölü havzasının hidrojeolojik özelliklerinin belirlenmesi, göl ile havza ilişkisinin ortaya konması, göl su rezervinin optimum kullanımı ve su kalitesinin kontrolü açısından önemlidir. Eğirdir Gölü havzasının kuzey batısında yer alan Hoyran (Kumdanlı) havzasındaki evsel atık sularından kaynaklanan olası yüzey ve yeraltısuyu kirliliğinin Eğirdir Gölü’ne etkilerinin belirlenmesi ve Eğirdir Gölü su kalitesinin uzun zaman periyodunda korunması açısında yapılacak yeraltısuyu akım modellemesi büyük önem taşımaktadır.

Çalışma alanındaki hidrolojik ve hidrojeolojik verilerin, arazi çalışmalarında doğrudan arazi veri kayıt sistemine aktarılmasıyla oluşturulmuş olan veri tabanın, yeraltısuyu akım modellemesinde kullanılarak modelin hassassiyeti ve doğruluğu artırılmıştır.

Hoyran (Kumdanlı) havzasında yapılmış önceki yeraltısuyu bütçe çalışmalarında (Topçam ve ark., 1977; Soyaslan , 2004), hidrolojik su bütçesi yöntemi kullanılmıştır. Bu yönteme göre elde edilen sonuçların kullanılabilirlikleri tartışılarak ve ortaya çıkabilecek eksiklikler üzerinde durulmuştur. Hidrolojik su bütçesi hesaplama yöntemlerine göre çok daha hassas olan yeraltısuyu akım modellemesi sonucunda elde edilen veriler ile önceki çalışmaların sonuçlarının karşılaştırılması amaçlanmaktadır.

\section{Materyal ve Metot}

\subsection{Materyal}

Bu bölümde, çalışma alanı konumunun genel bir tanıtımı, morfolojik özellikleri, hâkim iklim ve bitki örtüsü hakkında genel tanıtıcı bilgiler ortaya konulmuştur.

\subsection{1. Çalışma Alanı}

Çalışma alanı, Eğirdir Gölü’ne boşalan Hoyran Deresi su toplama havzasını kapsamaktadır. Havza, Göller bölgesinde Eğirdir Gölü su toplama havzası içerisinde ve gölün kuzey doğusunda yer almaktadır (Şekil 1). Isparta iline yaklaşık olarak 80 km uzaklıktaki çalışma alanında, Kumdanlı, Mısırlı, Sağır, Körküler, Gökçeali, Aşağı Tırtar ve Yukarı Tırtar yerleşimleri bulunmaktadır. Çalışma sahası yaklaşık olarak $311 \mathrm{~km}^{2}$ bir alan kapsamakta ve 1/100.000 ölçekli topoğrafik haritada Afyon L25 ve L26 paftaları içinde kalmaktadır. Yerleşim merkezleri çoğunlukla Pliyosen, Miyosen, Kuvaterner yaşlı çökellerin oluşturduğu tarım alanları üzerinde yer almaktadir. 


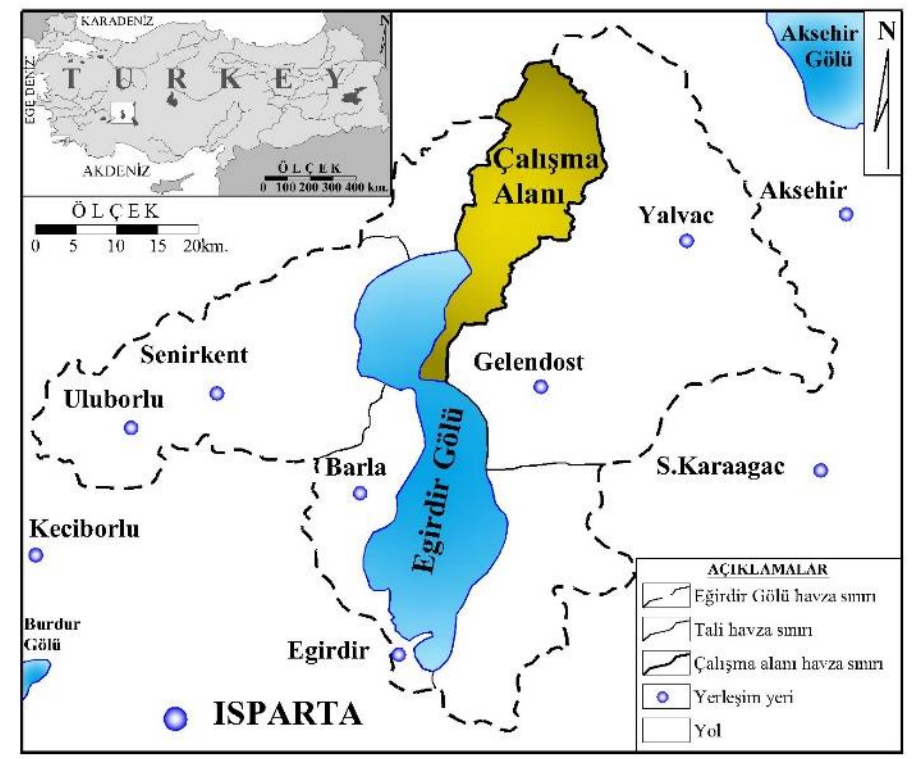

Şekil 1. Çalışma alanının yerbulduru haritası

\subsubsection{Jeomorfoloji}

Çalışma alanı içersinde yaşlı birimler yükseltileri, genç birimler alçak ve peneplen topografyayı oluşturmaktadırlar. Doğuda Sultandağları yükseltisi, güneyde Anamasdağ yükseltisi horst yapıları olarak karşımıza çıkmaktadır. Eğirdir Gölü ile batıya doğru Kumdanlı havzasını kapsayan çukurluk alan ise grabeni oluşturmaktadır. Özellikle Sultandağ metamofikleri ve çalışma alanı dışında güneyde yeralan Anamasdağ karbonatları ile Neojen çökeller arasında olan dokanaklar boyunca tektonizmanın da etkili olduğu oldukça sarp ve keskin bir topografya gözlenmektedir.

Bölgede yer alan önemli yerleşim merkezi olarak Yalvaç ilçesine bağlı köy ve belediyeler yer almaktadır. Bunlar; Kumdanlı, Körküler, Mısırlı, Sağır, Gökçeali, Yukarıtırtar ve Aşağıtırtar'dır. Yerleşim merkezleri çoğunlukla Pliyosen, Miyosen, Kuvaterner yaşlı çökellerin oluşturduğu tarım alanları üzerinde yer almaktadır.

\subsection{3. İklim ve Bitki Örtüsü}

Akdeniz Bölgesi içinde yer alan çalışma alanı, iklim özellikleri bakımından Akdeniz ve İç Anadolu arasında geçiş tipini karakterize etmektedir. Yani bazı iklim özellikleri ile Akdeniz iklimine, bazı özellikleriyle de İç Anadolu iklimine benzerlik göstermektedir. Yazları sıcak ve kurak, kışları ılık ve yağışlıdır. Sonbahar ve ilkbaharda zaman zaman yağış alabilen bölge, kış aylarında da yağışı dönemler geçirebilmektedir. Bu genel tanımlama içinde saha, Doğu Akdeniz provensinin güney kısmı ile Doğu Anadolu yarı çöl kuşağı arasındaki geçiş bölgesinde kalır. Bu geçiş bölgesinde yer alan çalışma alanı, iklim ve bitki örtüsü açısından karmaşık bir yapı arz eder (Ünald1, 1990).

Çalışma alanı bitki örtüsü bakımından genelde fakirdir. Ovalar ve düşük kotlu topografyanın yayvan olduğu kesimler genellikle tarım arazileri olduğu için bu kesimlerde buğday, arpa, yulaf gibi tahıl ürünleri, şeker pancarı, haşhaş, ayçiçeği gibi tarla ürünleri, sebze, meyve ağaçlarından oluşan otsu ve odunsu flora gözlenmektedir.

\subsection{Yöntemler}

Yeraltısuyu akım modellemesinin başarısı, başlangıç aşamasında geliştirilmesi gereken kavramsal modelin doğru bir şekilde kurulmasına bağlıdır. Kavramsal modelin doğruluk ve hassaslığı ise çalışma alanının stratigrafik, hidolojik, hidrojeolojik, morfolojik ve topoğrafik yapısının doğru bir şekilde ortaya konmasına bağlıdır. Bu bölümde kavramsal modelin temelini oluşturan bu özellikler detaylı olarak açıklanmıştır.

\subsubsection{Stratigrafi ve Petrografi}

Çalışma alanının stratigrafik ve yapısal özelliklerinin ortaya konulması amacıyla jeoloji haritasının hazırlanması kaya birimi ayırtlamasına dayandırılmıştır. Birimlerin özgül niteliklerinin tanımlanması ve çökelme ortamlarının belirlenmesi amacıyla önceki çalışmalar ayrıntılı olarak incelenmiştir. Bu veriler arazi çalışmaları ile desteklenmiş ve bu aşamada arazi veri kayıt sistemi kullanılarak, birimler stratigrafik ve petrografik özelliklerine göre ayırt edilerek çalışma alanının genelleştirilmiş stratigrafik sütun kesiti ve 1/25.000 ölçekli detay olarak jeoloji haritası hazırlanmıştır.

\subsubsection{Hidroloji}

Yeraltısuyu bilançosu yapılmasına yönelik olarak havza içerisinde ve çevresinde bulunan toplam sekiz adet Devlet Meteoroloji İstasyonu verilerinden yararlanılmıştır. Çalışma alanına düşen ortalama yağış miktarı, aritmetik ortalama, Thiessen poligon (çokgen) ve eşyağış (izohiyet) eğrileri yöntemleri kullanılarak tespit edilmiştir. Potansiyel ve gerçek buharlaşma değerleri, Thornthwaite, Blaney-Cridle ve Schendel yöntemleri kullanılarak hesaplanmış ve bu yöntemler için deneştirmeli su bilançosu yapılmıştır. Havza 
içerisinde kaynak boşalımından ve yağıştan beslenerek Eğirdir Gölü’ne dökülen Hoyran deresinin ortalama yıllık akım miktarları DSİ'den alınarak, çalışma alanından Eğirdir Gölü'ne yıllık ortalama boşalım miktarı belirlenmiştir.

\subsubsection{Hidrojeoloji}

Başlangıçta çalışma alanı sınırlarının belirlenmesi amacıyla 1/100.000 ölçekli topoğrafik haritalardan taslak olarak çizilen havzanın su bölüm hattı, 1/25.000 topoğrafik haritalar kullanılarak kontrolleri yapılarak düzeltme ve detaylandırma çalışmaları ile doğruluk ve hassaslığı artırılmıştır. Bu çalışmalar sırasıdnan arazide topoğrafik olarak ulaşılabilen su bölüm hattı noktaları gps kullanılarak koordinatları belirlenmiştir. Çalışma alanındaki drenaj ağları 1/25000 ölçekli topoğrafik haritalar kullanılarak ayrıntılı olarak çalışılması sonucunda çalışma alanının drenaj ağı haritası hazırlanmış olup, özellikle yeraltısuyu akım modellemesine yönelik olarak hoyran deresi akış güzergâhı üzerinde odaklanılarak çalışılmıştır.

Çalışma alanındaki jeolojik birimlerin hidrojeolojik özelliklerine göre akiferler tanımlanmıştır. Akifer karakteristiklerinin (K, T, S) hesaplanması, akiferlerdeki su potansiyelinin doğru işletilmesi, havzada ve eğirdir gölü su kalitesinin uzun dönemde korunmasının tartışılması amacıyla önem taşımaktadır. DSİ ve Köy Hizmetlerinin kuyularına ait pompaj deney sonuçları kullanılarak, Aquifer Test Pro 3.7 bilgisayar programında gözenekli akifer için Cooper-Jacob, Thies, Neuman yöntemleri, karstik akifer için Moench yöntemi ile akifer karakteristikleri hesaplanmıştır. Tüm bu çalışmalar sonucunda çalışma alanı, yeraltısuyu işletmesine uygunluk açısından hidrojeolojik özelliklerine göre değerlendirilerek bölgelere ayrılmış ve tüm bu veriler yeraltısuyu akım modellemesinde kullanılmıştır.

\subsubsection{Yeraltısuyu Akım Modellemesi}

Üç boyutlu sonlu farklar yeraltısuyu akım modeli olan MODFLOW-88 McDonald ve Harbaugh (1988)veya MODFLOW-96 Harbaugh ve McDonald (1996) tarafından geliştirilmiş ve şu anda en çok kullanılan ve güvenilir yeraltısuyu akım modellerinden biridir. Advektif taşınım modeli PMPATH (Chiang 1994; Chiang ve Kinzelbach, 1993; Chiang vd., 1998), madde taşınım modeli MT3D (Zheng, 1990), MT3DMS (Zheng and Wang, 1998) ve parametre tahmin programlar1 PEST (Doherty et al., 1994) ve UCODE (Poeter \& Hill, 1988) bu yaklaşımda kullanılmış olan MODFLOW tabanlı modellerdir.

Hoyran (Kumdanlı) havzasında yeraltısuyu akışının ve potansiyelinin belirlenmesi amacıyla Processing Modflow for Windows (PMWIN) 5.0 yazılım programı kullanılarak yeraltısuyu akış modellemesi yapılımıştır. PMWIN programında akifer sisteminin sınır koşulları modeli güney batısında Eğirdir Gölü sabit seviyeli hidrolik yük ve diğer yerlerin tamamı ise akım olmayan sınır koşulları olarak modellenmiştir.

Kavramsal modelin oluşturulması aşamasında modeli oluşturan dört farklı tabaka ve bu tabakalara ait alt ve üst seviye kotları tanımlanmıştır. Jeolojik ve hidrojeolojik yapıya bağlı olarak sınır koşulları ve hidrojeolojik parametreler belirlendikten sonra, PMWIN programında değişken büyüklükte grid ağları oluşturularak her akifer tabakası 17 x 25 olmak üzere 425 hücreye bölünmüştür. MODFLOW için gerekli en önemli girdi olan yeraltısuyu beslenme miktarı ve gözlem kuyularındaki ölçümler, kaynaklardaki debi ölçümleri ve yeraltısuyu kullanım miktarları için yeraltısuyu seviye ölçümleriyle modelin kalibrasyonu yapılmıştır.

\section{Araştırma Sonuçları ve Tartışma}

\subsection{Stratigrafi ve Petrografi}

Arazi çalışmaları ile literatür taraması sonucu belirlenen çalışma alanının genel jeoloji haritası, yeraltısuyu akım modellemesine yönelik olarak revize edilmiştir. Özellikle çalışma alanında bulunan jeolojik birimlere ait dokanak sınırları arazi veri kayıt sistemi kullanılarak gps ile ayrıntılı olarak belirlenmiştir. Oluşturulan yeraltısuyu akım modellemesinin doğruluğu ve güvenirliliği, doğal jeolojik ortamı en iyi temsil eden verilerin sağlanması ile mümkün olmaktadır. Bu yüzden yeraltısuyu akım modellemesi yapılırken doğal sistemi en iyi şekilde belirlemek amacıyla arazide yapılan tüm ölçümler anında bilgisayara aktarılmıştır. Formasyon sınırları, faylar ve süreksizlik düzlemleri ayrıntılı olarak belirlenmiştir. Literatür bilgileri ile arazi çalışmaları arasında uyumsuzluğun meydana geldiği noktalar üzerinde yoğunlaşarak bu uyumsuzlukların ortadan kaldırılması sağlanarak tamamlanan çalışma alanının 1/100.000 ölçekli genel jeoloji haritası revize edilmiştir (Şekil 2).

Çalışma alanında jeolojik birimler, otokton ve allokton olmak üzere iki gruba ayrılmışlardır. Otokton birimler, alttan üste doğru Sultandede Formasyonu, Hacıalabaz Kireçtaşı, Yalvaç Neojen havzasını oluşturan tortullardan Yarıkkaya Formasyonu ve tüm birimlerin üzerine uyumsuz olarak gelen Alüvyon ve Yamaç Molozu'ndan oluşmaktadır. Allokton birim olarak Hoyran Ofiyoliti yer almaktadır. Sultandede Formasyonu, Ordovisiyen yaşlı düşük dereceli metamorfik kayalardan meydana gelmiştir. Formasyon, kahverengi metakumtaşı, fillit, sleyt, yersel pembe-boz renkli kuvarsit, metakuvarsit, kalsitler ile metakonglomera ve iri kristalli, mermer seviyelerinden oluşmaktadır. Mesozoyik, Üst Jura yaşlı Hacialabaz Kireçtaşı ile temsil edilmekte olup, koyu siyah renkli yer yer oolitli kireçtaşı, üste doğru koyu siyah renkli, ince-kalın katmanlı, kalsit damarlı, eklemli oobiyosparit, kristallenmiş biyomikrit, biyosparitten oluşmaktadır. Hoyran Ofiyoliti; serpantinit, diyabaz, çört, serpantinleşmiş dunit, peridoditten ve değişik boyutlardaki bloklardan ve olistrostromal kireçtaşından meydana gelmiştir. Yarıkkaya Formasyonu, çakıltaşı, kumtaşı, kiltaşı, killi kireçtaşı ve kireçtaşından oluşmaktadır. Temel kayalar üzerine uyumsuz olarak örten alüvyon, farklı boyuttaki blok, çakıl, kum, silt, kil ve bunların farklı kombinasyonlarının birikiminden meydana gelmektedir. Yamaç molozları ise, özellikle Beyşehir-Hoyran Napı'na bağlı gelişmiş eteklerinde ve sarp yamaçlarda yayılmış köşeli blok ve çakıl ve kırıntılardan oluşmaktadır (Soyaslan , 2004). 


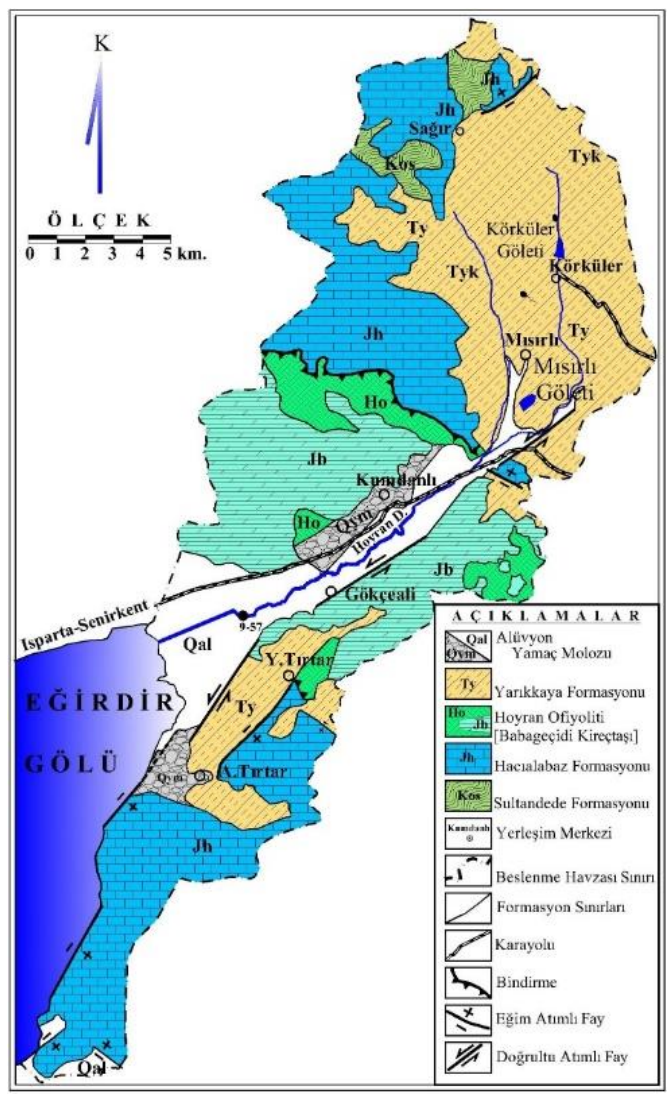

Şekil 2.. Hoyran Havzası jeoloji haritası

\subsection{Hidrojeoloji}

Arazi çalışmaları ile Isparta il özel idaresine bağlanan Köy Hizmetleri ve DSİ tarafından açılmış sondaj kuyularının kotları ve koordinatları tespit edilmiş, diğer akifer parametreleri ilgili kurumlardan alınmıştır (Tablo 1). Kamu kurumları tarafından açılmış derin sondaj kuyularına ilave olarak çalışma alanında bulunan keson kuyuların yeraltısuyu seviye ölçümleri, kuyu ağız kotları ve kuyu koordinatları belirlenmiştir.

Tablo 1. Çalışma alanındaki kamu kurumlarının sondaj kuyularına ait veriler

\begin{tabular}{|c|c|c|c|c|c|c|c|c|c|c|}
\hline \multirow{2}{*}{$\begin{array}{c}\text { Sira } \\
\text { No }\end{array}$} & \multirow{2}{*}{$\begin{array}{c}\text { Kuyu } \\
\text { Adı }\end{array}$} & \multirow{2}{*}{ Lokasyon } & \multicolumn{2}{|c|}{ Koordinatlar } & \multirow{2}{*}{$\begin{array}{c}\text { Pafta } \\
\text { No }\end{array}$} & \multirow{2}{*}{$\begin{array}{l}\text { Rakım } \\
\text { (m) }\end{array}$} & \multirow{2}{*}{$\begin{array}{c}\text { Derinlik } \\
\quad(m)\end{array}$} & \multirow{2}{*}{$\begin{array}{c}\text { Statik } \\
\text { Seviye } \\
(\mathrm{m}) \\
\end{array}$} & \multirow{2}{*}{$\begin{array}{c}\text { Dinamik } \\
\text { Seviye } \\
\text { (m) }\end{array}$} & \multirow{2}{*}{$\begin{array}{c}\text { Verim } \\
(Q p) \\
\text { lt/sn }\end{array}$} \\
\hline & & & Doğu & Kuzey & & & & & & \\
\hline 1 & KH10 & Misirli & 327725 & 4248125 & L26-a4 & 1066 & 44.00 & 2.60 & 11.60 & 5.00 \\
\hline 2 & KH11 & Ayvalı & 330950 & 4253450 & L26-a1 & 1296 & 62.00 & 20.00 & 40.00 & 3.00 \\
\hline 3 & 4232 & Hoyran & 316565 & 4240623 & L25-c3 & 922 & 158.50 & 13.65 & 31.00 & 2.00 \\
\hline 4 & 4567 & Hoyran & 320837 & 4240940 & L25-c3 & 944 & 500.00 & 22.40 & 50.10 & 0.60 \\
\hline 5 & 25336 & Kumdanlı & 317830 & 4241410 & L25-c3 & 932 & 93.00 & \multicolumn{3}{|c|}{ KUYU KURU } \\
\hline 3 & 25337 & Kumdanlı & 318855 & 4240930 & L25-c3 & 942 & 150.00 & 6.15 & 9.34 & 58.47 \\
\hline 4 & 25338 & Kumdanlı & 319473 & 4241188 & L25-c3 & 956 & 60.00 & 16.10 & 30.74 & 40.62 \\
\hline 6 & 25339 & Kumdanlı & 320451 & 4241492 & L25-c3 & 950 & 62.00 & 34.00 & 40.00 & 34.58 \\
\hline 7 & 25340 & Kumdanlı & 320770 & 4241540 & L25-c3 & 947 & 70.00 & 38.70 & 39.60 & 57.97 \\
\hline 8 & 22235 & Hoyran & 323539 & 4243696 & L25-c3 & 997 & 225.00 & 4.55 & 13.82 & 60.62 \\
\hline 5 & 22236 & Hoyran & 322045 & 4242520 & L25-c3 & 957 & 220.00 & 4.15 & 30.31 & 49.26 \\
\hline 6 & 22237 & Hoyran & 318040 & 4241130 & L25-c3 & 938 & 117.00 & 16.75 & 21.85 & 61.06 \\
\hline 9 & 22238 & Hoyran & 317408 & 4240805 & L25-c3 & 924 & 220.00 & 5.45 & 27.66 & 35.32 \\
\hline 10 & 22239 & Hoyran & 316585 & 4241712 & L25-c3 & 935 & 40.00 & 12.95 & 17.31 & 62.32 \\
\hline
\end{tabular}

Süreksizlik analizleri sonucunda, çalışma alanındaki egemen süreksizliklerin eğim yönlerinin (GB-KB) Eğirdir Gölü’ne doğru olması ve sahip oldukları yüksek eğim (87-86) derecelerinden dolayı, yüzey suyunun ve yeraltısuyunun çalışma alanından Eğirdir 
Gölü’ne doğru olan hareketini kolaylaştırmaktadırlar. Süreksizlik analizine ilave olarak yapılan uzaktan algılama çalışmaları sonucunda karstik akiferden Eğirdir Gölü’ne yeraltısuyu boşalımı olduğu tespit edilmiştir (Şener \& Soyaslan, 2006).

Çizgiselliklerin büyük bölümünün çalışma alanındaki tektonizmadan yoğun olarak etkilenmiş olan Hacıalabaz ve Sultandede Formasyonu üzerindeki süreksizlikleri ve drenaj ağlarını temsil etmektedir. Çalışma alanında bulunan süreksizlik düzlemleri, yeraltısuyu hareketi açısından ayrı bir öneme sahiptir. Bu sebepten dolayı, süreksizliklerin istatistiksel değerlendirmesi ve uzaktan algılama çalışmaları, çalışma alanının tabanında yer alması ve karstik akiferi oluşturmasından dolayı sadece Hacıalabaz Formasyonu'nda yapılmıştır (Şener \& Soyaslan, 2006).

Çizgiselliklerin büyük bölümünün çalışma alanındaki tektonizmadan yoğun olarak etkilenmiş olan Hacıalabaz ve Sultandede Formasyonu üzerindeki süreksizlikleri ve drenaj ağlarını temsil ettiği belirlenmiştir. Çalışma alanında bulunan süreksizlik düzlemleri, yeraltısuyu hareketi açısından ayrı bir öneme sahiptir.

Senirkent-Yalvaç kara yolunun takiben Gökçeali köyü yol ayrımındaki Hoyran Dere'si üzerinde 3056"D-38¹7"K koordinatlarında ve $950 \mathrm{~m}$ kotunda bulunan DSİne ait 09-57 nolu Gökçeali akım rasat istasyonu verileri alınarak değerlendirilerek aylık ortalama akım debi grafiği hazırlanmıştır (Şekil 3). Hoyran deresinin 1996-2017 yılları arasındaki ortalama akım debileri, yeraltısuyu akım modellemesinde kullanılmak üzere değerlendirilmiştir.

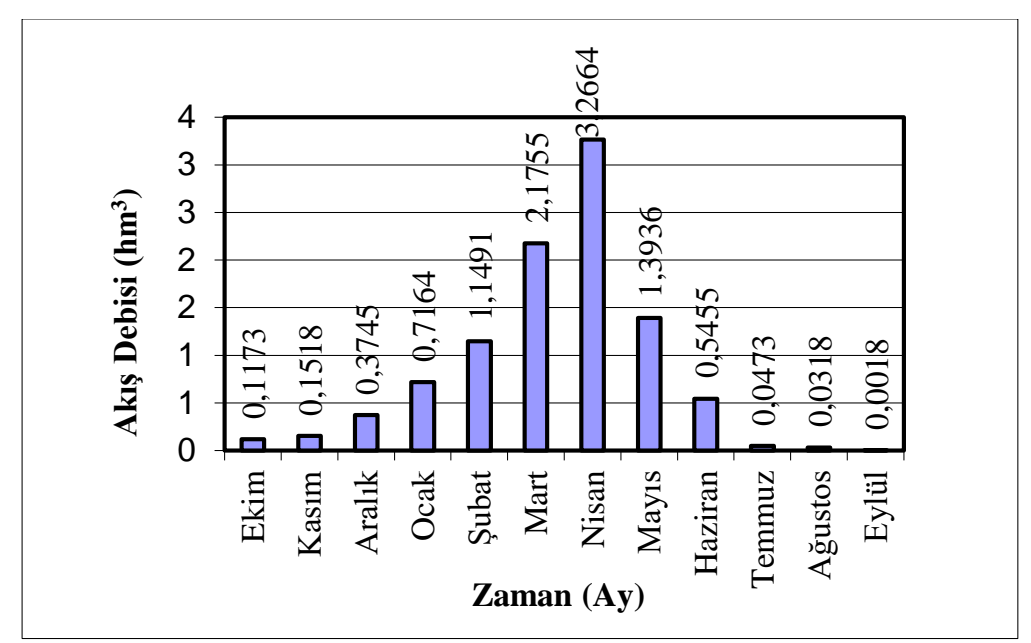

Şekil 3. Hoyran Deresi aylık ortalama akım debileri

\subsection{Yeraltısuyu Akım Modellemesi}

Arazi çalışmaları sonucunda, çalışma alanında yapılacak yeraltısuyu akım modellemesinin temelini teşkil eden kavramsal modelin en önemli öğesi olan grid ağları oluşturulmuştur (Şekil 4). Grid ağlarının oluşturulmasında grid hücrelerinin büyüklükleri ve sıklıkları çalışma alanının genel jeolojisi dikkate alınarak belirlenmiştir. Bu aşamada oluşturulan hücrelerin içerisinde birden fazla litolojik birimin bulunması durumunda, hücrenin hâkim litolojisinin belirlenmesi büyük bir sorun olarak karşımıza çıkmaktadır. Oluşturulan hücrenin hakim litolojisinin belirlenmesi amacıyla çalışma alanında GPS kullanılarak sayısal olarak hücre sınırları içerisindeki birimlerin formasyon sınırları ayrıntılı olarak belirlenerek hücrenin hakim litolojisi tespit edilmiştir. Yeraltısuyu akım modellemesinin başarısı kavramsal modelin arazi özelliklerinin gerçeğe en yakın olarak temsil edilmesine bağlı olmasından dolayı kavramsal model aşamasında karşılaşılacak her türlü problemin çözümünde GPS kullanılarak sayısal arazi analizi yapılmıştır.

Simülasyonumuz kararlı akım (steady-state) şartları için kabul edilerek yapıldığından dolayı, zamanla ilgili parametreler, depolama katsayısı ve özgül verim gibi parametrelere ihtiyaç yoktur. Yeraltısuyu akım modellemesinde kullanılan MODFLOW herhangi bir yeraltısuyu sistemini $\mathrm{Z}$ yönünde tabakalar halinde modellemektedir. Bu yüzden MODFLOW'da bulunan 4 temel tabaka tipinden çalışma alanımızda bulunan 3 farklı tabaka tipi kullanılarak modellenmiştir. 


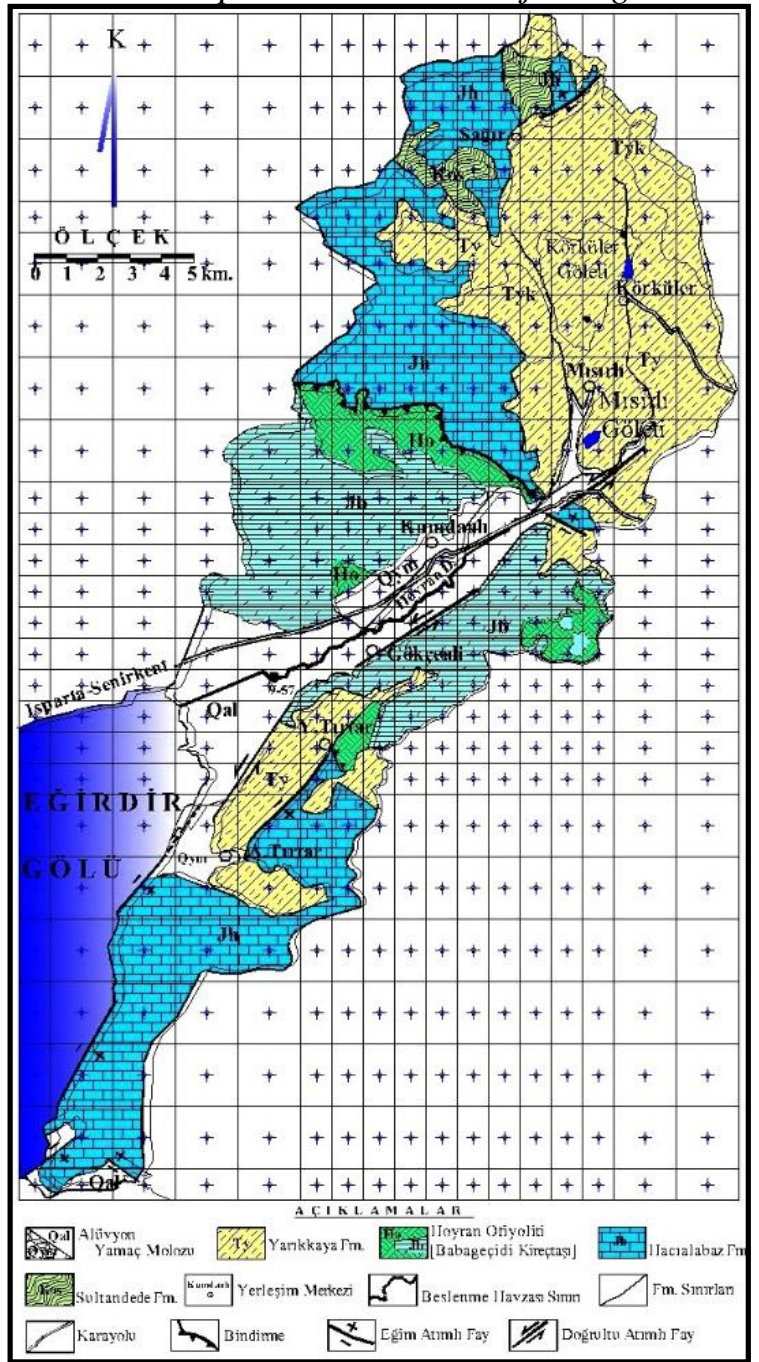

Şekil 4. Yeraltısuyu akım modellemesi amacıyla oluşturulan çalışma alanın grid ă̆

Modflow'da modellemede kullanılan 4 temel tipi şunlardır;

Tip 0; Bu tabaka tipi, tüm simülasyon zamanı için her bir hücrenin transmisibilitesinin sabit kaldığı basınçlı akiferin simülasyonunda kullanılır. Modelimizde Tip 0 tabaka tipi kullanılmamıştır. Çünkü her bir tabaka çalışma alanımızda yüzeylenmektedir.

Tip 1; Bu tabaka tipi, sadece en üstteki ilk tabaka için geçerlidir ve serbest yüzeyli akifer için uygulanır. Tabakanın transmisibilitesi, simülasyon boyunca akiferin doymuş kalınlığına bağlı olarak değişim gösterir (Kresic, 1997). Modelimizde serbest akifer olarak modellenen alüvyon (K1) birimi Tip 1 tabaka olarak modellenmiştir.

Tip 2; Bu tip tabaka, serbest yüzeyli ve basınçlı akifer tipinde olan akiferler için kullanılır. Ancak, simülasyon periyodu boyunca sabit olan transmisibilitenin tekrar hesaplanması gerekli değildir, bu yüzden tabaka kalınlığının büyük bir kısmının doymuş olduğu varsayılır. Modelimizde karstik akifer karakterindeki Hacıalabaz Formasyonu ile Babageçidi kireçtaşı (K4) Tip 2 tabaka olarak modellenmiştir.

Tip 3; Bu tip bir tabaka, basınçlı-basınçsız geçişleri içinde kullanılır. Her tekrarlamada kullanılan hidrolik iletkenlik ve yeni doymuş kalınlık tarafından tekrar hesaplanan değişen transmisibiliteye sahiptir. Yarıkkaya Formasyonu (K2) ve Sultandede Formasyonu, Hoyran ofiyoliti (K3) Tip 3 tabaka olarak modellenmiştir.

Tabakalar alüvyon (K1) en üsstte, onun altında Yarıkkaya Formasyonu (K2) ve Sultandede formasyonu, Hoyran ofiyoliti (K3) en altta ise Hacıalabaz formasyonu ile Babageçidi kireçtaşları (K4) yer almaktadır. Eğer tabaka K4 en üstte bulunuyorsa onun üzerinde bulunması gereken üç tabaka (K1, K2 ve K3) inaktif olarak modellenmiş ve tabaka kalınlıkları önemsenmeyecek kadar küçük (0.01 m) modellenmiştir.

Çalışma alanında yapılan yeraltısuyu akım modellemesinin temelini teşkil eden kavramsal modelin en önemli öğesi olan grid ağları her bir model tabakası için ayrı ayrı oluşturulmuştur (Şekil 5). Bu dönem hazırlanmış olan grid ağları üzerinde çalışma alanında bulunan jeolojik birimler 4 ana model tabakasına ayrılarak her bir model hücresi için bu tabakalara ait alt ve üst seviye kotları girilmiştir. Model tabakaların alt ve üst seviye kotları girilirken mevcut sondaj kuyularına ait sondaj logları ile jeoloji haritası üzerinden alınan kesitlerden yararlanılmıştır. 

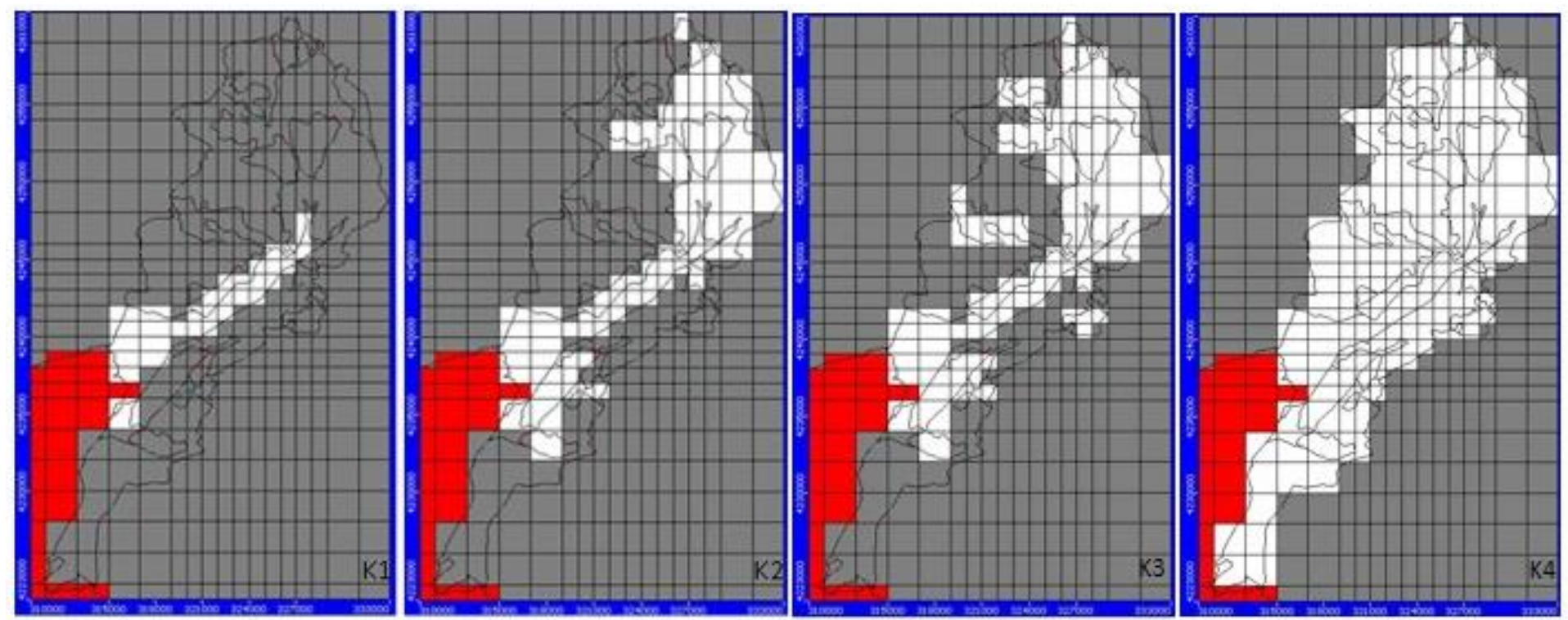

Şekil 5. Çalışma alanındaki dört model tabakası için (K1-K2-K3-K4) oluşturulan grid ă̆l

Yatay anizotropi katsayısı 1, düşey anizotropi katsayısı ise parametreler seçenek listesinden düşey hidrolik iletkenlik seçilerek belirlenebilen ve tabaka için kullanılan düşey hidrolik iletkenlik $\mathrm{V}_{\mathrm{K}}$ seçilmiştir (Tablo 2).

Tablo 2. Başlangıçta kullanılan tabakalara ait hidrojeolojik parametreler

\begin{tabular}{c|c|c|c|c}
\hline Tabaka Adı & Formasyon Adı & Tabaka Tipi & $\begin{array}{l}\text { Yatay Hidrolik } \\
\text { İletkenlik (m/gün) }\end{array}$ & $\begin{array}{l}\text { Düşey Hidrolik } \\
\text { İletkenlik (m/gün) }\end{array}$ \\
\hline K1 & Alüvyon/Yamaç Molozu & Tip 1 & 0,5 & 0,05 \\
\hline K2 & Yarıkkaya Fm. & Tip3 & 0,05 & 0,005 \\
\hline K3 & $\begin{array}{c}\text { Sultandede Fm. ve } \\
\text { Hoyran Ofiyoliti }\end{array}$ & Tip3 & 0,01 & 0,001 \\
\hline K4 & $\begin{array}{c}\text { Hacıalabaz Fm. Ve } \\
\text { Babageçidi Kçt. }\end{array}$ & Tip2 & 10 & 55 \\
\hline
\end{tabular}

Yeraltısuyu akım modeli kurulacak akifer sistemi serbest yüzeyli akifer ve basınçlı karstik akifer özelliğindedir. Yüzeyde yer alan alüvyon ve Neojene ait tortullar serbest yüzeyli akifer, temel kayayı oluşturan kireçtaşları ise karstik basınçlı akifer özelliğindedir. Çalışma alanındaki sondaj logları, enine kesitler ve jeofizik çalışmaları dayanarak tabakalara ait tavan ve taban kotları belirlenmiştir. Modellemede kullanılan maksimum taban kotu olarak $600 \mathrm{~m}$ olarak alınmıştır.

Yeraltısuyu modellemesi sırasında PMWIN tarafından desteklenen PCG2 çözüm paketi kullanılmıştır. PCG2 çözüm paketi için gerekli olan ve modelde kullanılan parametreler Şekil 6'daki Ön Koşullanma Eşlenik Gradyan Paketi 2 diyalog kutusunda belirtilmiştir. Bu parametreler aşağıda tanımlanmıştır.

İzin Verilmiş İterasyon Sayısı: MXITER, dıştaki iterasyonların maksimum sayısıdır. Lineer bir problem için, MXITER 50 iç iterasyondan daha fazlasına ihtiyaç duyulmadıkça 1 olabilir. Nonlineer problemler için genellikle 1 ile 100 arasında değerler alabilir. Modelimizde iterasyon sayısı 90 alınmıştır. Yakınsama Kriteri: Ardışık iki iterasyon arasındaki maksimum hidrolik seviye değişimi [L], verilen yakınsama kriterinden daha küçük olunca iterasyon durur. Modelimizde yakınsama kriterine 0.01 değeri verilmiştir. 


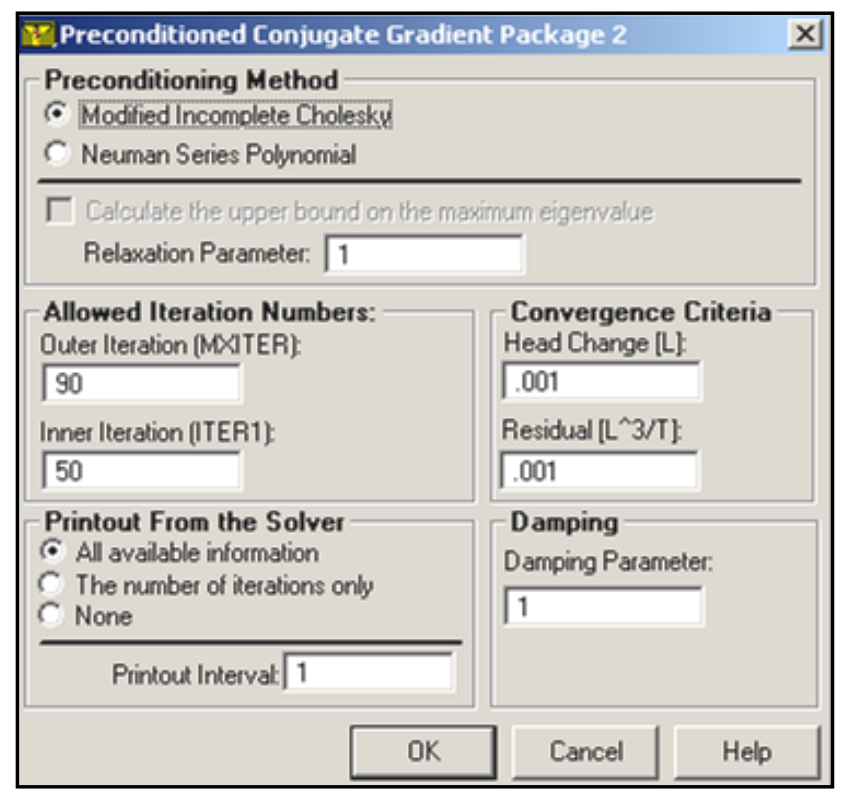

Şekil 6. Koşullanma Eşlenik Gradyan Paketi 2 diyalog kutusu

Simülasyonumuz kararlı akım (steady-state) olduğu için zamanla ilgili parametreler, depolama katsayısı ve özgül verim gibi parametrelere ihtiyaç yoktur.

Çalışma alanı kapalı bir havza özelliği taşımasından dolayı yeraltısuyu beslenmenin temel kaynağı yağıştır. Çalışma alanından boşalım buharlaşma, kaynaklar, Hoyran Deresi ve yaklaşık 4 km'lik kıyı şeridi boyunca yeraltısuyu akımı ile Eğirdir Gölü'ne olmaktadır. Hoyran Dere'sinden Eğirdir Gölü’ne olan akımın mevsimsel olup yaz aylarından kurumasından dolayı model içerisine alınmamış sadece toplam yıllık yağış miktarından çıkarılmıştır. Eğirdir Gölü’ne olan yeraltısuyu akımı ise göl seviyesi ile yeraltısuyu seviyesi arasındaki farka bağlı olarak model tarafından hesaplanmaktadır.

Yağış (Recharge): Çalışma alanı ve çevresindeki meteoroloji istasyonu verileri kullanılarak bulunan ortalama yağış miktarlarının çalışma alanını temsil etmediği görülmüştür. Bu sebepten dolayı, yeraltısuyu akım modellemesinde modelin temel beslenimi olan yağış miktarı olarak, Kumdanlı DMİ tarafından ölçülmüş 391.09 mm'lik ortalama yağış kullanılmıştır. Hesaplanmış olan 391.02 mm'lik ortalama yağışın 304.43 mm'lik kısmı buharlaşarak 86.59 mm'lik net yağış değeri elde edilmiştir. Hoyran Deresinden Eğirdir Gölüne olan ortalama akım miktarı 10.65 x $106 \mathrm{~m}^{3}$ çıkarılıp, DSİ sulamaları ile Eğirdir Gölü’nden çekilen 1.1 x $106 \mathrm{~m}^{3}$ eklendiğinde, 300 x $106 \mathrm{~m}^{2}$ lik model alanına düşen beslenme miktarı $0.05469 \mathrm{~m} / \mathrm{y}$ ll olarak bulunmuştur. Model içerisinde ortalama beslenme miktarı $0.00015 \mathrm{~m}$ /gün olarak kullanılmıștır. Model alanı içerisindeki toplam beslenme miktarı değişmemek koşuluyla, kalibrasyon sırasında hücrelerin morfolojik ve litolojik özellikleri ile sulama yapılan alanlar göz önüne alınarak hücrelere 0-0.021 m/gün arasında değişen beslenme değerleri verilmiştir. Drenaj ağlarının çok iyi geliştiği yüksek eğimli Hoyran Ofiyoliti ve Sultandede formasyonu üzerindeki (K3) tabakasına ait hücrelerde beslenme değerleri düşürülürken, drenaj ağlarından gelen yüzeysel akımın sebep olduğu beslenme etkisi ovalık alandaki hücrelerde beslenme değerinin artırılması ile sağlanmıştır.

Kaynak (Drain): Kaynaklar, MODFLOW'da Drain paketi kullanılarak modellenir ve iki parametre ile tanımlanmaktadır. Birinci parametre kaynağın hidrolik iletkenliği $(\mathrm{Cd})\left[\mathrm{L}^{2} / \mathrm{T}\right]$, kaynak ile akifer arasındaki tüm enerji kayıplarını içine alan bir katsayıdır. İkinci parametre kaynak havuzunun su yüksekliğidir (d) [L]. Her kaynak için bir parametre numarası verilebilir ve bu parametre numarası, ters modellerde otomatik kalibrasyon için Cd yerine parametre atamakta kullanılır.

Kaynağın bulunduğu hücrelerdeki hidrolik seviye, kaynak yüksekliğinden daha büyük olduğu zaman yeraltısuyu kaynağa doğru boşalır ve bu boşalım kaynak suyu olarak modelden dişarı çıkar. Bu durumda kaynak boşalımı varmış gibi modellenir. Hidrolik seviye kaynağın yüksekliğine eşit yada daha düşük olduğu zaman kaynaktaki boşalım sıfır olur. Akiferdeki hidrolik seviyeye dikkate alınmaksızın kaynaktan beslenim daima sıfır olur ve kaynak kuruymuş gibi modellenir.

Çalışma alanındaki kaynakların 1977 yılına ait debileri DSİ tarafından belirlenmiştir. 1977 yılındaki yıllık ortalama yağış miktarı, ortalama yağış miktarına orantılanarak modelde kullanılacak kaynak debileri belirlenmiştir. Kaynakların bulunduğu hücrelerdeki hidrolik seviyenin, kaynak yüksekliğinden daha yüksek olmasından dolayı dren boşalımı olmaktadır.

Kuyular (Well): Bir pompaj yada enjeksiyon kuyusu, MODFLOW'un Well paketi ile iki parametreyle tanımlanmaktadır. Bu değerler kuyudan su çekilme ve enjeksiyon oranı $(\mathrm{Q})\left[\mathrm{L}^{3} / \mathrm{T}\right]$ ve parametre numarasıdır. Kuyunun su çekilme oranı negatif, enjeksiyon oranı pozitif değerler ile belirlenir. Parametre numarası, ters modellerde otomatik kalibrasyon için Q yerine parametre atamakta kullanılmıştır.

Kararlı akım simülasyonunda bir kuyunun enjeksiyon yada pompaj oranı simülasyon boyunca sabittir ve hücredeki hidrolik seviye ile hücre alanına bağlıdır. MODFLOW, hücrenin tüm kalınlığının kuyu tarafından kesildiğini dolaylı olarak kabul eder. MODFLOW bir model tabakasından daha fazlasını kesen kuyuların benzetimini yapabilir. Bu durumda her bir tabaka için enjeksiyon 
ve pompaj oranı belirtilebilir. Çok tabakayı kesen kuyular için enjeksiyon ve pompaj oranı toplamı, her bir tabakadan yapılan pompaj değerlerinin toplamına eşittir olarak modele girilmiştir.

Çalışma alanındaki üretim kuyularından DSİ ile Köy Hizmetlerine ait sondaj kuyuları değerlendirilmiştir. İlgili kurumların kendi kuyularının ve özel kuyuların tahmini üretim miktarları belirlenmiştir. Bu verilere ilave olarak arazi çalışmaları sırasında ruhsatı bulunmayan çok sayıda üretim kuyusunun bulunduğu gözlenmiştir. Üretim miktarları belirlenirken, tarım alanlarının dağılımı ve tarım alanlarındaki su açıkları dikkate alınarak ruhsatsız kuyuların üretim miktarları tahmin edilmiştir. Bu tahmini üretim miktarları diğer kuyular üzerine eklenerek, modellemede kullanılan üretim kuyularının çalışma alanının genelini temsil etmesi sağlanmıştır. Bazı üretim kuyularının farklı tabakaları kestiği durumlarda sondaj logları dikkate alınarak toplam üretim miktarı kesilen tabakalar arasında oransal olarak paylaştırılmıştır.

Seviye Gözlem Kuyuları (Head Observation): Gözlem kuyularının isimleri, koordinatları (doğu [x], kuzey [y]), kesilen tabaka oranları ve yeraltısuyu seviyeleri girilmiştir. Yeraltısuyu seviyeleri kullanılarak hesaplanan hidrolik seviyeler, gözlenen değerlere en uygun hale gelinceye kadar kalibrasyon yapılmıştır.

\subsubsection{Yeraltısuyu Akım Modelinin Kalibrasyonu}

Çalışma alanında alüvyon ve Neojene ait tortullardan oluşan serbest akifer ve temel kayayı oluşturan karstik kireçtaşı akiferi bulunmaktadır. DSİ ve Köy Hizmetlerine ait pompaj verileri bulunan sondaj kuyularının büyük bölümü gözenekli serbest akiferi temsil etmekte çok az bir kısmı ise her iki akiferi birden temsil etmektedir. Kalibrasyonda kullandığımız gözlem kuyularındaki yeraltısuyu seviyelerine dayanarak, yeraltısuyu akım modelinin kalibrasyonu serbest akifer için daha hassas yapılmıştır.

Model içerisinde kullanılmadan kalibrasyon çalışmalarında modelin tutarlılığını kontrol eden tek parametre arazide ölçülmüş yeraltısuyu statik seviyeleridir. Bu sebeple kalibrasyonda kullanılacak gözlem kuyularının bölgedeki yeraltısuyu seviyelerini temsil etmesi, kalibrasyon ve modelin başarısı açısından son derece önemlidir. Birbirine çok yakın bulunan gözlem kuyularından, bölgenin hidrojeolojik yapısına uygun değerlere sahip olmadığı için bölgeyi temsil etmediği veya hatalı ölçüm yapıldığı düşünülen üç adet kuyu kalibrasyona dâhil edilmemiştir.

Yeraltısuyu akımının çalışma alanından Eğirdir Gölü’ne doğru olması sebebiyle uzun zaman periyodunda hidrolik yük eğiminin etkisi ile yeraltısuyu akımı kendine giderek genişleyen bir yol bulmaktadır. Bu sebepten dolayı model alanından Eğirdir Gölü sahil şeridine doğru yatay iletkenlik değeri giderek artmaktadır. Hoyran ovalarındaki özellikle Kumdanlı güneybatısındaki yüksek debili yeraltısuyu üretimi bunun bir göstergesidir.

Kalibrasyon çalışmalarında kuyuların bulunduğu hücrelerde gözlenen yeraltısuyu seviyeleri ile model tarafindan hesaplanan yeraltısuyu seviye değerlerinin karşılaştırılması yapılmıştır. Gözlenen ve hesaplanan yeraltısuyu seviyeleri arasındaki yaklaşımı sağlayabilmek için kalibrasyon parameteresi olarak yatay ve düşey hidrolik iletkenlik değerleri kullanılmıştır (Tablo 3.).

Tablo 3. Kalibrasyon sonucu elde edilen yatay ve düşey hidrolik iletkenlikler

\begin{tabular}{c|c|c|c|c}
\hline Tabaka Adı & Formasyon Adı & Tabaka Tipi & $\begin{array}{c}\text { Yatay Hidrolik } \\
\text { Iletkenlik (m/gün) }\end{array}$ & $\begin{array}{c}\text { Düşey Hidrolik } \\
\text { İletkenlik (m/gün) }\end{array}$ \\
\hline K1 & Alüvyon/Yamaç Molozu & Tip 1 & $0,07-7$ & $0,000013-2$ \\
\hline K2 & Yarıkkaya Fm. & Tip3 & $0,0001-1,5$ & $0,0001-0,2$ \\
\hline K3 & $\begin{array}{c}\text { Sultandede Fm ve Hoyran } \\
\text { Ofiyoliti }\end{array}$ & Tip3 & $0,00-0,15$ & $0,0001-0,001$ \\
\hline & $\begin{array}{c}\text { Hacialabaz Fm. ve } \\
\text { Babageçidi Kçt. }\end{array}$ & Tip2 & $1-38$ & 5 \\
\hline
\end{tabular}

Gözlenen ve hesaplanan değerler arasındaki fark en aza indirildiğinde kalibrasyon işlemi tamamlanmıştır. Gözlem kuyularının büyük bölümün çalışma alanının batı-güneybatısında toplanması, kuzey ve doğuda hesaplanan yeraltısuyu seviyelerinin kontrolünün yapılamamasına sebep olmuştur.

PMWIN, gözlem kuyularına ait gözlenen ve model tarafından hesaplanan yeraltısuyu seviye değerlerini karşılaştırarak grafiksel olarak aralarındaki istatistiksel ilişkiyi göstermektedir (Şekil 7.). Kalibrasyonun sonucunda hesaplanan ve gözlenen yeraltısuyu seviyeleri arasındaki ilişkiyi temsil eden grafik üzerindeki noktaların konumlarının, gözlenen ve hesaplanan değerlerin eşit olduğu doğruya yakın olduğu görülmektedir. Hesaplanan ve gözlenen yeraltısuyu seviyeleri $918.55 \mathrm{~m}$ ile $1063.4 \mathrm{~m}$ değerleri arasında değişmektedir. 


\section{Avrupa Bilim ve Teknoloji Dergisi}

Serbest akifer için model tarafindan hesaplanan yeraltısuyu seviyeleri ile gözlenen yeraltısuyu seviyeleri arasındaki fark $+3.2 \mathrm{~m}$ ile $2.8 \mathrm{~m}$ arasında değişmektedir. Gözlenen ve hesaplanan hidrolik seviyelere ait standart sapma değeri $1.81 \mathrm{~m}$ olarak bulunmuştur.

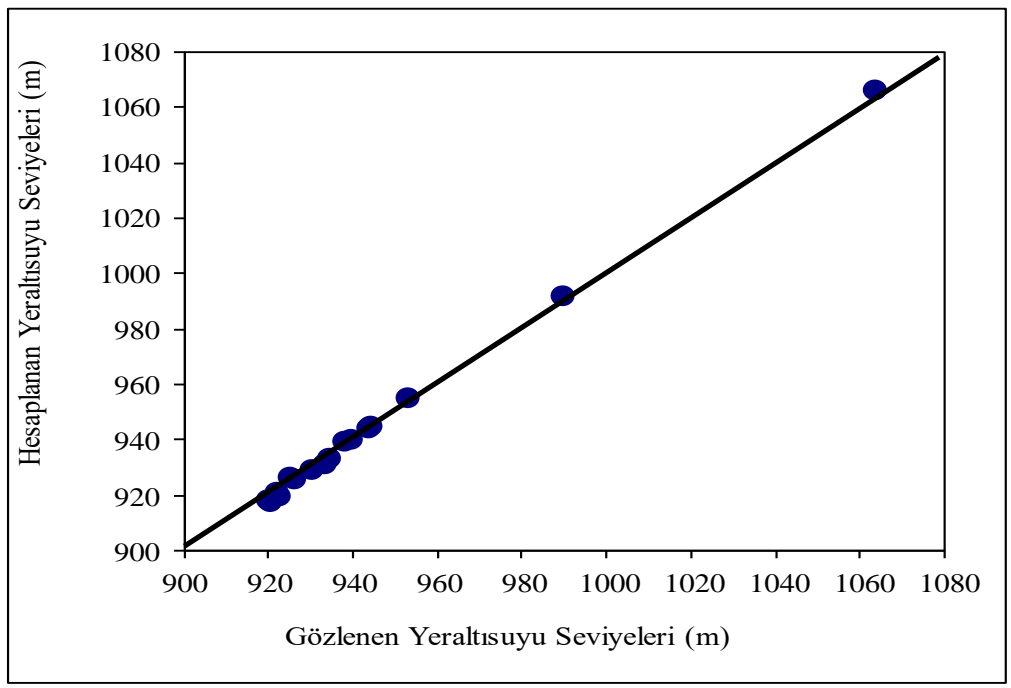

Şekil 7. Kalibrasyon sonucunda gözlenen ve hesaplanan yeraltısuyu seviyelerinin karşılaş̧tırma grafiği

Hesaplanan ve gözlenen yeraltısuyu seviye değerleri arasındaki fark genellikle gözlem kuyularının az bulunduğu Kuzeydoğu kesimlerinde artış göstermektedir. Model alanının Kuzeydoğusunda yer alan Mısırlı bölgesinde hesaplanan değerin büyük olması sonucu fark $+3.2 \mathrm{~m}$ değerine kadar çıkmaktadır. Çalışma alanının Güneybatıda yer alan Aşağııırtar kuzeyinde ise yine gözlem değerlerinin büyük olması sonucunda fark $-2.8 \mathrm{~m}$ değerine kadar çıkmaktadır. Bunun yanında Hoyran (Kumdanlı) ovasında gözlem kuyularının sayılarındaki artışa bağlı olarak fark ideal olan $-1.0 \mathrm{~m}$ ile $+1.0 \mathrm{~m}$ değerleri arasında değişmektedir. Buda gösteriyor ki, modelleme ile benzetimin başarısı elde bulunan verilerin sayısı ile doğru orantılı olarak değişmektedir. Benzetimde ve kalibrasyonda kullanılacak ne kadar çok veri olursa benzetimde o kadar gerçeğe yakın olarak yapılabilmektedir.

Karstik kireçtaşı akiferi için kalibre edilmiş yeraltısuyu seviye haritasında, üç nolu tabakanın altında (K3) kireçtaşı (K4) inaktif olmasından dolayı çalışma alanının batı kesimlerinde yeraltısuyu seviye konturları çizilmemiştir. Bu bölgedeki kireçtaşı kalınlığı minimum $(0.01 \mathrm{~m})$ olarak alınmış ve üç nolu tabakaya (K3) ait hidrojeolojik değerler kullanılmıştır.

\subsubsection{Yeralttsuyu Akım Modellemesiyle Hazırlanan Su Bütçesi}

Su bütçesi Hoyran (Kumdanlı) havzasında yeraltısuyu akım modellemesinden yararlanarak hazırlanmışıtr. Şekil 8.'de verilen su bütçesinde dört model tabakası için ayrı ayrı beslenim ve boşalım miktarları hem debi $\left(\mathrm{m}^{3} / \mathrm{yl}\right)$ hem de oran (\%) olarak verilmiştir (Motz \& Doğan, 2003).

Hoyran havzasında yeraltısuyunun temel beslenim kaynağı yağıştır. Yapılan yeraltısuyu akım modellemesinde $300 \times 10^{6} \mathrm{~m}^{2}$ olan model alanındaki beslenimin \% 99.2'si yağıştan $\left(142.20 \times 10^{6} \mathrm{~m}^{3} / \mathrm{y} 1 \mathrm{l}\right), \% 0.8^{\prime}$ 'ü ise sulama suyundan $\left(1.10 \times 10^{6} \mathrm{~m}^{3} / \mathrm{yl}\right.$ l) olmak üzere toplam $143.3 \times 10^{6} \mathrm{~m}^{3} / \mathrm{y}$ l' 'dır. Beslenimin \% 63.6'sı buharlaşmakta $\left(91.09 \times 10^{6} \mathrm{~m}^{3} / \mathrm{y} 1\right)$, \% 7.4'ü yüzeysel akışa geçmekte $\left(10.65 \times 10^{6}\right.$ $\left.\mathrm{m}^{3} / \mathrm{y} 1 \mathrm{l}\right)$ ve $\% 29$ 'u $\left(41.56 \times 10^{6} \mathrm{~m}^{3} / \mathrm{y} 1 \mathrm{l}\right)$ ise yeraltına süzülerek yeraltısuyunu beslemektedir.

Modelde kullanılan tabakaların hepsinin model alanı içerisinde yüzeye çıkmasından dolayı yeraltısuyu beslenimi her dört tabakada da gerçekleşmiştir. Toplam yeraltısuyu besleniminin $\left(41.56 \times 10^{6} \mathrm{~m}^{3} / \mathrm{yll}\right), \% 10.38$ 'i serbest akiferi oluşturan birinci tabakada $\left(4.28 \times 10^{6} \mathrm{~m}^{3} / \mathrm{yl}\right), \% 36.6$ 'i yarı ve az geçirimli ikinci tabakada $\left(9.56 \times 10^{6} \mathrm{~m}^{3} / \mathrm{yl} l\right), \% 5.5^{\prime}$ 'i geçirimsiz üçüncü tabakada $\left(0.96 \times 10^{6}\right.$ $\left.\mathrm{m}^{3} / \mathrm{y} 1 \mathrm{l}\right), \% 48^{\prime}$ lik en büyük bölümü ise karstik kireçtaşı akiferinde $\left(26.76 \times 10^{6} \mathrm{~m}^{3} / \mathrm{y} 1\right)$ gerçekleşmektedir.

Alüvyondan oluşan serbest akiferde gerçekleşen $5.48 \times 10^{6} \mathrm{~m}^{3} / \mathrm{y} 1$ toplam akım miktarında beslenimin $\% 78$ 'si yağıştan $(4.28 \mathrm{x}$ $\left.10^{6} \mathrm{~m}^{3} / \mathrm{yl} 1\right)$, \%22'i ikinci tabakadan $\left(1.20 \times 10^{6} \mathrm{~m}^{3} / \mathrm{y} 1 \mathrm{l}\right)$ yukarıya sızma ile gerçekleşmektedir. Boşalımın miktarının \% $4^{\prime}$ ü kaynaklardan boşalımı $\left(0.2 \times 10^{6} \mathrm{~m}^{3} / \mathrm{yl}\right), \% 9^{\prime}$ u kuyulardan çekim $\left(0.471 .49 \times 10^{6} \mathrm{~m}^{3} / \mathrm{yll}\right) \% 10^{\prime}$ u Eğirdir Gölü’ne $\left(0.6 \times 10^{6} \mathrm{~m}^{3} / \mathrm{y}^{\prime} \mathrm{l}\right)$, ve \%77'sı ikinci tabakaya $\left(4.21 \times 10^{6} \mathrm{~m}^{3} / \mathrm{y} 1 \mathrm{l}\right)$ aşağıya sızma ile gerçekleşmektedir. 


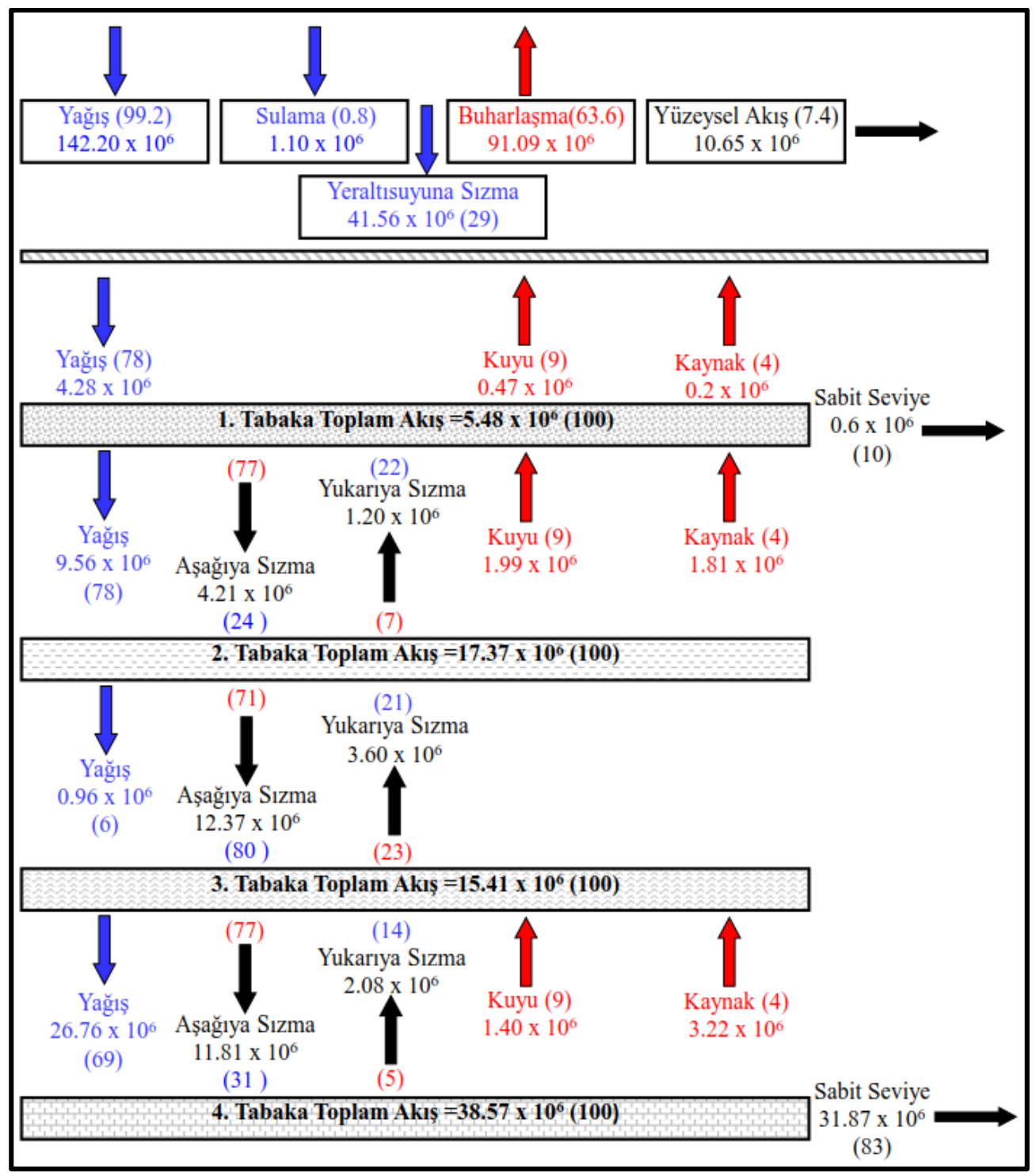

Şekil 8. Hoyran havzasının yeraltısuyu modellemesi sonunda oluşan su bütçesi

Yarı ve az geçirimli ikinci tabakada gerçekleşen 17.37 x $10^{6} \mathrm{~m}^{3} / \mathrm{y}$ ıl toplam akım miktarında beslenim miktarının \% 55 'si yağıştan (9.56 x $\left.10^{6} \mathrm{~m}^{3} / \mathrm{y} 1 \mathrm{l}\right), \% 24^{\prime}$ ü birinci tabakadan aşağıya sızma $\left(4.21 \times 10^{6} \mathrm{~m}^{3} / \mathrm{y} 1 \mathrm{l}\right), \% 21$ 'i ise üçüncü tabakadan $\left(3.6 \mathrm{x} 10^{6} \mathrm{~m}^{3} / \mathrm{y} 1 \mathrm{l}\right)$ yukarıya sızma ile gerçekleşmektedir. Boşalımın miktarının \% 12'si kaynaklardan boşalımı (1.99 x 106 $\left.\mathrm{m}^{3} / \mathrm{y}_{1}\right)$, \%10'u kuyulardan çekim $\left(1.81 \times 10^{6} \mathrm{~m}^{3} / \mathrm{y} 1 \mathrm{l}\right), \%$ 's 'si birinci tabakaya yukarı sızma ile $\left(1.20 \times 10^{6} \mathrm{~m}^{3} / \mathrm{y} 1 \mathrm{l}\right)$ ve $\% 71$ 'i üçüncü tabakaya $\left(12.37 \mathrm{x} 10^{6} \mathrm{~m}^{3} / \mathrm{y} 1 \mathrm{l}\right)$ sizmaktadir.

Geçirimsiz olarak modellenen üçüncü tabakada gerçekleşen 15.41 x $106 \mathrm{~m}^{3} / \mathrm{y}$ 1l'lık toplam akım miktarında beslenimin \% 6’sı yağıştan $\left(0.96 \times 10^{6} \mathrm{~m}^{3} / \mathrm{y} 1 \mathrm{l}\right), \% 80$ 'i ikinci tabakadan $\left(12.37 \times 10^{6} \mathrm{~m}^{3} /\right.$ yıl $)$ aşağıya sızmayla, \%14'ü ise dördüncü tabakadan yukarıya sızma $\left(2.08 \times 10^{6} \mathrm{~m}^{3} / \mathrm{y}\right.$ 1l) ile gerçekleşmektedir. Boşalımın miktarının \% 23 '̈̈ ise ikinci tabakaya yukarıya sızma ile $\left(3.60 \times 10^{6}\right.$ $\mathrm{m}^{3} /$ yıl) ve \%77'si dördüncü tabakaya (11.81 x $10^{6} \mathrm{~m}^{3} / \mathrm{y} 1$ ) sımaktadır. Bu tabaka içerisinde üretim kuyusu ve kaynak bulunmamaktadır. Geçirimsiz olan bu tabakadaki üretim miktarı ise modelleme içerisinde gösterilemeyecek kadar küçük ve karmaşık bir yapıda bulunan ofiyolit içerisindeki olistolit kireçtaşlarındaki kuyulardan kaynaklanmaktadır.

Modelin en altında yer alan karstik kireçtaşlarından oluşan dördüncü tabakada yıllık 38.57 x $10^{6} \mathrm{~m}^{3} / \mathrm{y}_{1} \mathrm{l}^{\prime} \mathrm{l} \mathrm{k}$ toplam akım miktarında beslenimin \% 69'u yağıştan (26.76 x $\left.10^{6} \mathrm{~m}^{3} / \mathrm{y} 1 \mathrm{l}\right)$, \%31'i üçüncü tabakadan $\left(11.81 \mathrm{x} 10^{6} \mathrm{~m}^{3} / \mathrm{y}_{1} \mathrm{l}\right)$ aşağıya sızmayla gerçekleşmektedir. Boşalımın miktarının \% 4'ü kaynaklardan boşalımı (1.40 x 106 m³/yıl), \%8'i kuyulardan çekim (3.22 x $10^{6}$ $\left.\mathrm{m}^{3} / \mathrm{y} 1 \mathrm{l}\right), \% 5$ 'i üçüncü tabakaya yukarı sızma ile $\left(2.08\right.$ x $\left.10^{6} \mathrm{~m}^{3} / \mathrm{y} 1 \mathrm{l}\right)$ ve \%83'ü Eğirdir Gölü’ne $\left(31.87\right.$ x $\left.10^{6} \mathrm{~m}^{3} / \mathrm{y}_{1} \mathrm{l}\right)$ boşalmaktadır.

Sonuç olarak çalışma alanından yeraltısuyuna süzülen beslenim miktarı 41.56 x $10^{6} \mathrm{~m}^{3} / \mathrm{y}$ 1l'ın \%13'ü kuyulardan (5.5 x $10^{6}$ $\mathrm{m}^{3} /$ yıl $)$ çekilmekte, \%9'u kaynaklardan (3.59 x $\left.10^{6} \mathrm{~m}^{3} / \mathrm{y} 1 \mathrm{l}\right)$ boşalmakta ve \%78'i sabit seviye olarak modellenen Eğirdir Gölü’ne (32.47 x $\left.10^{6} \mathrm{~m}^{3} / \mathrm{y} ı \mathrm{l}\right)$ boşalmaktadır. Çalışma alanındaki en büyük toplam akış debisine sahip olan akifer, dördüncü tabaka olarak modellenen karstik kireçtaşı akiferidir. 


\section{Sonuç}

Çalışma alanında bulunan jeolojik birimlere ait dokanak sınırları, fay ve süreksizlik düzlemleri arazi veri kayıt sistemi kullanılarak belirlenmiştir. Çalışma alanı sınırlarının belirlenmesi amacıyla 1/100.000 ölçekli topoğrafik haritalardan taslak olarak çizilen havzanın su bölüm hattı, 1/25.000 topoğrafik haritalar kullanılarak kontrolleri yapılarak düzeltme ve detaylandırma çalışmaları ile doğruluk ve hassaslı̆̆ı artırılmıştır. Özellikle yeraltısuyu akım modellemesine yönelik olarak Hoyran deresi güzergahı üzerinde odaklanılarak çalışılmıştır.

Derin sondaj kuyularına ait sondaj logları temin edilerek, ayrıntılı sondaj logları hazırlanmıştır. Arazi çalışmaları ile Köy Hizmetleri ve DSİ tarafından açılmış sondaj kuyuları ve keson kuyuların koordinatları ve kuyu ağız kotları belirlenmiştir. Akifer karakteristikleri incelendiğinde karstik akifer bölge için önemli bir yeraltısuyu potansiyeline sahiptir. Landsat ETM+ uydu görüntüleri kullanılarak karstik kireçtaşlarında K40-60D ve K30-60B olarak belirlenen hakim çizgisellik doğrultularının arazide ölçülen süreksizlikler ile uyumlu olduğu görülmüştür.

Hoyran Dere'si üzerinde bulunan DSİ'ne ait akım rasat istasyonu verileri yeraltısuyu akım modellemesinde kullanılmak üzere değerlendirilmiştir. Yeraltısuyu akım modellemesinde kullanılmak üzere çalışma alanındaki yağış, buharlaşma, yüzeysel akış, suni beslenme değerleri belirlenmiştir. Yeraltısuyu akım modellemesinde kullanılmak üzere çalışma alanında bulunan kaynaklar, kuyular ve seviye gözlem kuyuları modele aktarılarak model çalıştırılmıştır. Bir sonraki dönemde model kalibrasyonu yapılmıştır. Yeraltısuyu akım modellemesi tamamlandıktan sonra her bir model tabakası için ayrıntılı su bütçesi yapılmıştır.

Hoyran havzasında yeraltısuyu akışının ve potansiyelinin belirlenmesi amacıyla PMWIN (Processing Modflow) programı kullanılarak yeraltısuyu akış modellemesi yapılmıştır. Bu amaçla jeolojik ve hidrojeolojik yapıya bağlı olarak sınır koşulları ve hidrojeolojik parametreler belirlendikten sonra, PMWIN programında grid ağları oluşturulmuş, tabaka tipleri ve konumları ile diğer model parametreleri girilmiştir. DSİ tarafından model alanındaki yeraltısuyu seviye ölçümleri kullanılarak modelin kalibrasyonu yapılmış ve modelin hidrolik parametrelere karşı davranışı ve duyarlılığı belirlenmiştir. Yeraltısuyu akım modellemesi sonucunda çalışma alanından yeraltısuyuna süzülen beslenim miktarı 41.56 x $10^{6} \mathrm{~m}^{3} / \mathrm{yl} \mathbf{l}^{\prime} \mathrm{\prime n} \% 13$ 'ü kuyulardan $\left(5.5\right.$ x $\left.10^{6} \mathrm{~m}^{3} / \mathrm{y} 1 \mathrm{l}\right)$ çekilmekte, \%9'u kaynaklardan (3.59 x $\left.10^{6} \mathrm{~m}^{3} / \mathrm{y} 1\right)$ boşalmakta ve \%78'i sabit seviye olarak modellenen Eğirdir Gölü'ne $\left(32.47\right.$ x $\left.10^{6} \mathrm{~m}^{3} / \mathrm{yl}^{1}\right)$ boşalmaktadır. Çalışma alanındaki en büyük toplam akış debisine sahip olan akifer, dördüncü tabaka olarak modellenen karstik kireçtaşı akiferidir.

Model alanında gelecek yıllarda oluşabilecek farklı hidrojeolojik durumlarda hidrojeolojik yapıyı etkileyen tüm parametreler, bu parametrelerin yapı üzerindeki etkileri ve hidrojeolojik yapının tepkilerinin önceden belirlenebilecektir. Bu parametrelerin önceden belirlenmesi akiferin korunması açısından son derece önemlidir. Modelleme alanı içerisinden yeraltısuyu akımının bu tatlı su rezervuarına boşaldığı göz önüne alınırsa, Eğirdir Gölü’nün tatı su rezervuarı olarak kirletici etkilerden korunmasına yönelik korunma tedbirlerinin alınması açısından çalışma alanı için taşınım modellemesinin yapılması yararlı olacaktır.

\section{Kaynakça}

Abbas, S., Xuan, Y., and Bailey, R. (2018). Improving River Flow Simulation Using a Coupled Surface-Groundwater Model for Integrated Water Resources Management. EPiC Series in Engineering, 3,1-9.

Berehanu, B., Ayenew, T., Azagegn, T. (2017). Challenges of Groundwater Flow Model Calibration Using MODFLOW in Ethiopia; With Particular Emphasis to the Upper Awash River Basin. Journal of Geoscience and Environment Protection, 5, 50-66.

Birhanu, D. (2012). Numerical Groundwater Flow Modeling of the Meki River Catchment, Central Ethiopia. Unpublished MSc Thesis, Addis Ababa University, Addis Ababa.

Boyraz, U. (2011). Hidrolojik Modellemede Yüzey Suyu-Yeraltı Suyu Etkileşimlerinin Önemi, 5. Ulusal Su Mühendisliği Sempozyumu, 12-16 Eylül, İstanbul.

Chiang, W., H., Kinzelbach, W. (1993). Processing Modflow (PM), Pre- and postprocessors for the simulation of flow and contaminants transport in groundwater system with MODFLOW, MODPATH and MT3D.

Chiang, W.-H., Kinzelbach W., Rausch, R. (1998). Aquifer Simulation Model for Windows -Groundwater flow and transport modeling, an integrated program. Gebrüder Borntraeger Berlin, Stuttgart, ISBN 3-443-01039-3.

Chiang, W. H. (1994). PMPATH for Windows. User's manual. Scientific Software Group. Washington, DC.

Doherty, J., Brebber L., Whyte, P. (1994). PEST - Model-independent parameter estimation. User's manual. Watermark Computing. Australia.

Gebrekirstos, G. (2009). Groundwater Flow Assessment of the Aynalem Well Field through Transient Flow Modeling (Mekelle, Ethiopia). Unpublished MSc Thesis, Addis Ababa University, Ethiopia.

Guzman, J. A., Moriasi, D. N., Gowda, P. H., Steiner, J. L., Starks, P. J., Arnold, J. G., Srinivasan, R. (2015). A model integration framework for linking SWAT and MODFLOW, Environmental Modelling \& Software, 73, 103-116.

Harbaugh, A., W., McDonald, M. G. (1996a). User's documentation for MODFLOW-96, an update to the U.S. Geological Survey modular finite-difference ground-water flow model, USGS Open-File Report 96-485.

Harbaugh, A., W., McDonald, M. G., (1996b). Programmer's doumentation for MODFLOW-96, an update to the U.S. Geological Survey modular finite-difference ground-water flow model, USGS Open-File Report 96-486.

Hussien, R., Hagagg, K., El-Aassar, A., M., (2017). Coupling HYDRUS and MODFLOW for studying Environmental Impact of Wastewater Ponds in Tenth of Ramadan City, Egypt. The International Journal of Engineering and Science, 6 (10), 41-54. 
Guorui, W., Qiang, W., Zizhong, Y., Na, Z.,Chengbao, D., Xia, C., Hui, W. (2019). Fine Prediction for Mine Water Inflow on Basis of Visual Modflow. International Journal of Oil, Gas and Coal Engineering, 7(2), 52-59.

Kresic, N. (1997). Quantitative Solutions in Hydrogeology and Groundwater Modeling, Lewis Publishers, Boca Raton.

Lulu, S., Hiwot, A., Tsehayu, K. and Waltanigus, S. (2005). Groundwater Management Using Groundwater Modeling: Case Study on Akaki Well Field; Addis Ababa City, Ethiopia, International conference Kampala, Uganda.

McDonald, M. C., Harbaugh, A., W. (1988). MODFLOW, A modular three-dimensional finite difference ground-water flow model, U. S. Geological Survey, Open-file report 83-875, Chapter Al.

Motz, L.H., Dogan, A., (2003). North-Central Florida Active Water Table Regional Groundwater Flow Model (Final Report) November, Gainesville/Florida.

Poeter E., P., Hill, M., C. (1998). Documentation of UCODE, a computer code for universal inverse modeling, U.S. Geological Survey, Water-Resources Investigations Report 98-4080.

Soyaslan, I. I, (2004). Eğirdir Gölü doğusunun hidrojeoloji incelemesi ve yeraltısuyu modellemesi, Süleyman Demirel Üniversitesi, Fen Bilimleri Enstitüsü, Doktora Tezi (yayınlanmamış).

Tesfaye, A. (2009) Steady State Groundwater Flow and Contaminant Transport Modeling of Akaki Well Field and Its Surrounding Catchment (Addis Ababa, Ethiopia). Unpublished MSc Thesis, Addis Ababa University, Addis Ababa.

Topcam, A., vd., (1977). Devlet Su işleri Genel Müdürlüğü, Jeoteknik Hizmetler ve Yeraltısuları Dairesi Başkanlığı, HoyranGelendost ve Yalvaç Ovaları Hidrojeolojik Etüd Raporu, DSI, İşletme Müdürlüğü Matbaası, 56 s., Ankara.

Ünaldı, Ü. (1990). Eğirdir Gölü Doğusunun Fiziki Coğrafyası, İstanbul Üniversitesi, Sosyal Bilimler Enstitüsü, Türkiye Coğrafyası Anabilim Dalı, Doktora Tezi, 218 s., (yayınlanmamış).

Yitbarek, A. (2009). Hydrogeological and Hydrochemical Framework of Complex Volcanic System in the Upper Awash River Basin, Central Ethiopia: With Special Emphasis on Inter-Basins Groundwater Transfer between Blue Nile and Awash Rivers. Unpublished PhD Thesis, Addis Ababa University, Addis Ababa.

Zheng, C. (1990). MT3D, a modular three-dimensional transport model, S.S. Papadopulos \& Associates, Inc., Rockville, Maryland.

Zheng, C., Wang, P., P. (1998). MT3DMS, A modular three-dimensional multispecies transport model for simulation of advection, dispersion and chemical reactions of contaminants in groundwater systems. Documentation and user's guide. Departments of Geology and Mathematics, University of Alabama. 